\title{
Offshore Ontologies: Global Capital as Substance, Simulation, and the Supernatural
}

Samuel Weeks

Thomas Jefferson University

Follow this and additional works at: https://jdc.jefferson.edu/jchsfp

Part of the Anthropology Commons

\section{Let us know how access to this document benefits you}

\section{Recommended Citation}

Weeks, Samuel. 2020. "Offshore Ontologies: Global Capital as Substance, Simulation, and the Supernatural." Dialectical Anthropology 44(4):355-371.

This Article is brought to you for free and open access by the Jefferson Digital Commons. The Jefferson Digital Commons is a service of Thomas Jefferson University's Center for Teaching and Learning (CTL). The Commons is a showcase for Jefferson books and journals, peer-reviewed scholarly publications, unique historical collections from the University archives, and teaching tools. The Jefferson Digital Commons allows researchers and interested readers anywhere in the world to learn about and keep up to date with Jefferson scholarship. This article has been accepted for inclusion in College of Humanities and Sciences Faculty Papers by an authorized administrator of the Jefferson Digital Commons. For more information, please contact: JeffersonDigitalCommons@jefferson.edu. 
Dialectical Anthropology

“Offshore Ontologies: Global Capital as Substance, Simulation, and the Supernatural"

Samuel WEEKS, M.A., Ph.D.

Assistant Professor of Anthropology

College of Humanities and Sciences

Thomas Jefferson University

samuel.weeks@jefferson.edu

The following is a post-peer-review, pre-copyedit version of an article that has been published in Dialectical Anthropology. Here is the citation of the published article:

Weeks, Samuel (2020) "Offshore Ontologies: Global Capital as Substance, Simulation, and the Supernatural," Dialectical Anthropology 44.4, pp. 355-371.

https://link.springer.com/article/10.1007/s10624-020-09593-3

https://doi.org/10.1007/s10624-020-09593-3

Here is a link to the website of Dialectical Anthropology:

https://www.springer.com/journal/10624 


\title{
Offshore Ontologies: Global Capital as Substance, Simulation, and the Supernatural
}

Samuel Weeks, M.A., Ph.D.

Assistant Professor of Anthropology

Thomas Jefferson University

samuel.weeks@jefferson.edu

\begin{abstract}
In this article, I bring ontological anthropology into a register that is recognizably political and critical in orientation. My intention is to apply the powerful conceptual approach of the "ontological turn" in order to address a contemporary politico-economic problem of acute importance: offshore finance. Drawing from archival and ethnographic data collected in Luxembourg, I argue that officials from this country's offshore financial center have employed ontology in particular ways in the service of a drastically imbalanced global capitalist system. In doing so, I contend that anthropologists are not the only people at present engaged in an "ontological turn"; so too are the thousands of bankers, lawyers, fund administrators, and accountants currently at work in Luxembourg. Thus, in exposing anthropologists to a set of concurrent "ontologies," I move away from how the turn's proponents within the discipline have to date thought of their ontological explorations as pointing to a somehow more desirable and progressive future.
\end{abstract}

\section{KEYWORDS}

Ontological anthropology, offshore finance, Luxembourg, corporate personhood, political economy

\section{INTRODUCTION}

A prominent recent "turn" in the qualitative social sciences concerns ontology - the branch of philosophy long concerned with questions of being, existence, and materiality. If the number of publications and conference panels is any indication, the topic has caught in particular the imagination of anthropologists. In the broadest of senses, these studies of "ontology" are the result of ethnographic enquiries into the making and conceiving of worlds that emanate from, but also span, oft-held divisions between humans, animals, plants, and things. Given this purview, the question of ontology raises a set of conceptual and methodological challenges that, according to the approach's proponents, the field of anthropology seems uniquely capable of addressing (Hage 2012). Indeed, to the great relief of Sahlins (2013), the ontological turn has re-affirmed both alterity and interconnectedness as central problematics for the discipline.

This general orientation has resulted in an emerging body of literature that brings together a number of avant-garde transdisciplinary subcurrents: multispecies ethnography (Kohn 2013; Tsing 2015), post-humanism (Descola 2005; Braidotti 2013), Science and Technologies Studies and Actor-Network Theory (Latour 1984, 2005; Law and Hassard 1999), among others. Topics 
covered by ontologically minded anthropologists range from vast indigenous cosmologies from the Andes and Amazonia to Mongolia and Melanesia (Blaser 2013; Londoño Sulkin 2005; Viveiros de Castro 2009; Pedersen 2011; Kapferer 2011) to subtle, phenomenological explorations into the places, practices, and things of everyday life (Henare et al. 2007; Bennett 2010). Even as the above ontological approaches and areas of analysis reflect a great deal of internal diversity, they nonetheless harbor "a unifying principle for [an] analytics and poetics of anthropology beyond the human" (Bessire and Bond 2014: 441).

Yet it is in the political claims of ontological anthropology where the turn shows, in the eyes of partisans, its greatest promise - or the true nature of its delusion, as claim a growing number of detractors. To enthusiasts, the ontological turn is nothing less than ambitious new orientation for anthropology - less as a diagnosis of the intractable problems of our present reality, but rather as an exploration of "the possible, the could be" (Holbraad et al. 2014). In this version, the ethnographer focuses not on what might be traditionally thought of as "the political," but opts instead for alternatives that are as anticipatory as they are conceptually innovative. The political thus comes to denote, according to Kohn, "an ethical practice that can include and be transformed by the other kinds of beings with whom we share our lives and futures" (2015: 323).

In this light, to many ontologically inclined anthropologists, topics such as power, exploitation, suffering, and resistance are as implicated in the entire "modern project" (Latour 1991) that the group seeks to provincialize, or even eschew entirely. In the words of Jensen: "the very impetus of the ontological turn [is] to develop concepts and modes of description not limited to explaining everything with the standard Western categories of critique" (2017: 531). As a result, what becomes politically important - per this logic - are the radical alterities in our midst and the emancipatory alternatives they supposedly hold for us. All we need to do is go find them. In the words of Hage: ontological anthropology "encourages us to feel haunted at every moment of our lives by what we are [and] could be" (2012: 290).

Even as the political claims of ontological anthropology have generated curiosity, interest, even excitement, they have also attracted a not insignificant amount of criticism. As Viveiros de Castro, Holbraad, Kohn, and colleagues seek to re-orient anthropology's relation to the political and to critique, Bessire and Bond lament how their respective efforts "[narrow] the areas of legitimate concern and [widen] the scope of acceptable disregard within social research" (2014: 441). Even Kohn himself notes the concern that "general turn to ontology [could be] an apolitical or, worse, reactionary project, where the easy politics of a big abstract political problem... hides all the local problems in which political economy cannot be ignored" (2015: 322). To detractors, the political concerns of the ontological turn's proponents amount to a mere academic critique of knowledge and, more problematically, divert attention away from the actually existing social consequences entailed by historical and contemporary power relations and forms of domination. Bessire and Bond are particularly strident in their condemnation: "the alter-modern worlds discovered by elite [ontologists] provide redemptive inhabitation for the privileged few, while the global masses confront increasingly sharp forms and active processes of inequality and marginalization" (2014: 450).

In this article, I bring ontological analysis into a register that is recognizably political and critical in orientation, what Candea might call "the ontology of political turn" (2014). My intention here 
is to apply ontological anthropology's powerful and novel conceptual approach - such as its emphasis on ethical practice, interspecies relations, and the agency of things - in order to address a contemporary global problem of acute politico-economic importance: offshore finance. Building on its valuable insights, I seek to extend this diverse and contested body of scholarship as a means to a broader political end (cf. Boellstorff 2016: 387). Akin to the practitioners of ontological anthropology, I attempt this intervention via an ethnographic and discursive example. Drawing from data collected via 80 interviews, participant-observation, and archival research over a period of twelve months in the Grand Duchy of Luxembourg, ${ }^{1}$ I propose that officials from this country's offshore financial center (place financière) have deployed ontology in particular legal, economic, and juridical ways in the service of a drastically imbalanced global capitalist system.

Furthermore, I argue that - in a manner similar to those in the anthropological avant-garde - my interviewees have assumed an "ontological turn" themselves, summoning a novel set of subjects and relations via the use of distinctive analytic and technical tools. In this light, as I infer, those who work in the Luxembourg financial center are concerned with demonstrating that there is a set of distinct ontologies within their jurisdiction - ones where substance, form, place, and personhood are not like those in the world of capitalism, financial regulation, and law enforcement found "elsewhere."

For instance, while in Luxembourg, I was surprised by the ontological basis present in much of the debate surrounding the financial center. Many companies in the country, as I was often told, lack "substance" or are made of nothing but "paper." Their tax domicile, curiously enough, is located either "elsewhere" or even "nowhere" at all. In similarly bewildering manner, I found out that Luxembourg is home to thousands of "fictive" boards of directors and serves as the host for annual meetings that take place not actually, but "virtually." Likewise, I was perplexed to learn that particular kinds of companies in Luxembourg are assigned a "legal personhood" so humanlike that they can enjoy the mobility, free speech, and rights to privacy afforded to "natural persons." By wielding these and other ontological powers, officials in the Luxembourg financial center accordingly possess the "magical," if not "supernatural," ability to allow banks and other financial entities to operate "in shadow form."

In undertaking the analysis herein, I recognize the importance and contributions of the ontological turn, even as I proceed in two new directions. The first of these entails the politicoeconomic implications of the forms of ontology under anthropological scrutiny. While the turn's proponents generally see ontology as a means to conceive of innovative alternatives to often-dire current social circumstances, I instead show how five "ontologies," or ontological interventions,

\footnotetext{
${ }^{1}$ To initiate interviews and participant-observation with officials from the Luxembourg financial center, I formulated a set of methods premised on strategic networking via mutual acquaintances, within alumni associations, and at industry events. Once initial contacts were made, I would often meet my interviewees nearby their banks, law firms, or state offices at cafés teeming with other finance workers gathering for rendez-vous. Encounters in these elite milieus tended to follow specific "scripts" or "choreography" (Dörry 2016: 26), which I had to learn along the way - even though I do share some of the same social and cultural capital as my interviewees. For a more detailed account of my methods, access to participants, and positionality during this study, see Weeks 2018.
} 
utilized by those in the Luxembourg financial center - which concern substance, presence, simulation, personhood, and visibility ${ }^{2}$ - have played a key role in engendering some of the gravest social ills of our time, such as vast inequalities of income and wealth, widespread tax evasion, and rampant environmental degradation. Taking the analysis further, I contend that anthropologists are not the only people at present engaged in an "ontological turn"; so too are those thousands of bankers, lawyers, fund administrators, and accountants currently at work in Luxembourg. Thus, in exposing anthropologists to a set of concurrent ontologies, I seek to move away from how the turn's proponents within the discipline have to date thought of their ontological explorations as uniformly pointing to a somehow more desirable and progressive future.

As a counterpoint, I show how the ontological implications of the much of the activity in the Luxembourg financial center are politically regressive, if not dystopian. Since the 1950s, the "ontologists" 3 of the Luxembourg financial center have given companies domiciled in the country many of the rights afforded to individuals, at the same time that they have also guaranteed them the non-human-like characteristics of immateriality, placelessness, and anonymity. In other words, companies in Luxembourg sometime amount to persons, though - in other instances - they are instead treated as mere associations capable of asserting the will of their members (cf. Winkler 2018: xxiii). Such ontological dexterity in Luxembourg does not, in my opinion, represent a desirable future state of affairs, pace Holbraad et al. (2014) and Kohn (2015), but is rather indicative of the steady increase in scope and significance of offshore financial activity in the Grand Duchy and the global economy more generally. From this example, we can see that while ontology may very well entail the basis for a progressive and alternative future-to-be, it can also be deployed, to spectacular effect, in the service of global capital's regressive political intentions.

My second objective for this paper stems from calls by Fischer (2013), Bessire and Bond (2014), Tsing (2015), and others to steer anthropology's ontological turn onto manifestly more political and critical terrain. The world we cohabitate with other beings and things may very well hold "the possible, the could be," but it is also one with profoundly unequal distributions of power, resources, and opportunity. Applied to the case of my field site, the ontological "possible" on offer in the Luxembourg financial center is much worse than many "actual" and currently existing political economies. In the formulation of Bessire and Bond: ours is a world "composed of potentialities but also contingencies, of becoming but also violence, wherein immanence is never innocent of itself' (2014: 450). In this spirit, I take up the challenge of Hage in engaging with the ontological turn in order to "generate new problematics that are of pertinence to radical politics" (2012: 286). As such, it is in this overall context of peril and promise, misery and mirth where I situate my present exploration into ontological anthropology.

\footnotetext{
${ }^{2}$ I have included these five "offshore ontologies," and not others, for the simple reason that they were the ones that I came across most frequently in interviews and archival material.

${ }^{3}$ This is, of course, an etic distinction, not an emic one.
} 


\section{OFFSHORE ONTOLOGY \#1 - IMMATERIALITY}

Of all the ontological interventions that take place in the Luxembourg financial center, perhaps their most basic iteration concerns substance. When asked by a Financial Times reporter about a G20 initiative clamping down on companies that shift their profits to low-tax jurisdictions (such as Luxembourg) where they have little or no economic activity, the country's Minister of Finance Pierre Gramegna replied, "Companies that are here, that have very little substance, will have to decide if they want to stay and add substance... We're going to lose companies, but those that we are going to keep are going to add substance" (cited in Walker 2017; emphases added).

Reading between the lines, in this and many other examples, we see how hundreds of companies and financial entities in Luxembourg have long been accused of lacking "substance." They exist on paper - or, in these days, on a computer server ${ }^{4}$ - most always to reduce the tax burden of an individual or firm, but they usually do not employ people, pay taxes, or engage in "substantive" economic or commercial activity (Ötsch 2016: 322). In her analysis of similar arrangements in the Cayman Islands, Roberts believes that these companies' substance-less ontology

lends an air of illusion and make-believe to offshore financial centers. Illusion turns to paradox when it is considered that fictitious capital is a way of pushing over-accumulated capital into fixed capital, whereas in offshore centers the lack of fixity and physical presence is the salient characteristic (1994: 92).

While determining whether something has substance is usually an ontologically simple determination, in Luxembourg this is far from a straightforward question. As a local politician reminded me during an interview, there is no accepted definition as to what defines "economic substance" (interview, July 2016). As I have shown elsewhere (Weeks 2018: 122-128), sowing this kind of confusion is a time-tested tactic of those defenders of offshore financial centers in Luxembourg and elsewhere. If there is no consensus as to how officials across multiple jurisdictions define whether certain financial activities amount to acceptable or illegal behavior, then cooperation, let alone enforcement, among said jurisdictions becomes exceedingly difficult, if not impossible.

In the case of the Luxembourg financial center, this tactic was laid bare vis-à-vis the question of tax evasion in the 1980s and 90s. Tax evasion constituted, then as now, a criminal offense in Germany, whereas in Luxembourg it was subject to a mere "administrative penalty." Accordingly, how - Luxembourgish officials doth protest - were they to assist the German authorities in enforcing a law that they do not consider to be a crime in the first place? As we see in this and other examples, many of the rules dictating "acceptable" financial practice - as are defined in regulatory capitals such as Frankfurt, Brussels, or Washington, D.C. - simply do not apply in the case of Luxembourg. Likewise, as to what constitutes "economic substance" or "tax evasion" in other jurisdictions is, of course, irrelevant in the Grand Duchy. Putting this into

\footnotetext{
${ }^{4}$ Interestingly, many of the computer servers where the information of Luxembourg's financial institutions is stored are physically located in the Grand Duchy as well. As reported by CNBC, tiny Luxembourg hosts 20 percent of all "Tier IV" data centers within the European Union. A "Tier IV" distinction, the highest industry ranking, means that such data centers are appropriate for hosting "business-critical infrastructure" (Dvas 2015).
} 
ontological terms, it is not simply that there are multiple regulatory spaces in play, but rather it seems entirely different ways of designing economic life itself. This is not so much "diversity" as it is a plurality of contemporaneous economic worlds, which come together only at specific nodes or in places when those in Luxembourg financial center assent to it.

A similar dynamic is in play regarding the concept of substance. Over the course of my research, I came across at least two definitions. First, a senior civil servant (haut fonctionnaire) likened "substance" to decision-making via an annual company board meeting. This definition of substance, however, conjures up images of behavior typical to tax havens, wherein the board and senior management of a company descend on a low-tax jurisdiction on an infrequent basis in order to reduce taxation in some form or another. Not unsurprisingly, this interviewee's definition of substance is not shared by foreign tax authorities, particularly those of other EU member states such as France and Germany. Thomas writes, "Foreign fiscal authorities begin to show themselves more pugnacious and the questionnaires rain down. They demand to see the proof that the decisions have been effectively and integrally taken in Luxembourg and not merely on the paper of dummy administrators [administrateurs de pacotille]" (2016b).

A second definition came from another senior civil servant, who did little clear up the confusion, equating one ontological distinction, substance, to another: "real activities." Asked as to how this latter category is defined, my interviewee replied that it necessitates a headquarters with actual employees (interview, April 2016). As before, this interviewee's fear of substance-less companies run by dummy administrators evokes another staple of tax-haven jurisdictions: the ubiquity of firms offering "business services." A notorious example of this phenomenon can be found at 1209 North Orange Street in Wilmington, Delaware, USA, where a startling 285,000 businesses are registered for tax purposes (Neate 2016). In Luxembourg, the numbers are far more modest: one unassuming office block located at 5, rue Guillaume Kroll in the capital city nevertheless serves as the fiscal "home" to at least 1,600 companies (Smith 2014). Yet this is not the only such facility in Luxembourg; Local journalist Bernard Thomas notes, "business centers are seeing a current boom. We count currently 50 or so of these firms... which specialize in the niche of "business hospitality"' (2016b).

While my two interviewees seemed certain in their ontological pronouncements vis-à-vis substance of companies, others were less sure. In response to a question along these lines by Bernard Thomas, former director of Luxembourg's tax authority Guy Heintz replied that

The Luxembourg tax authorities recognize a company as Luxembourgish when its headquarters is located here. Afterwards, it's for the tax authorities of other countries to contest this fiscal residence. We have sent to our neighboring countries the names of firms that don't have activities here... These letters always remain without a response. Their fiscal administrations do not take these up. Probably because they do not have the means to verify these very complicated structures [montages]. It's not easy to determine the place of activities (2016a).

Nor is it easy, of course, to make the ontological determination as to what constitutes substance. Curiously, neither senior civil servant cited above is correct, according to current laws in Luxembourg; the much sought-after distinction of substance now necessitates more than just a board meeting or a staffed headquarters. Since 2011, a company can only reflect substance after 
meeting two criteria: "the existence of appropriate material installation" and the "regular presence of a manager."

Yet, in our age of "paperless" and flexible offices - to say nothing of the gig economy - the very conception of what a "workplace" entails has become even less clear. Further adding to the complexity of these arrangements, as Thomas notes, is that the terms and conditions for many business centers in Luxembourg feature something called a "an attributed surface mobility clause." In the words of one of these contracts: the renting company has therefore "no right to an exclusive lease in perpetuity [droit de jouissance] over said office" and "can be seen to take up an equivalent space in another part of the building" (cited in Thomas 2016b). Thus, via a business center, a Luxembourgish company can achieve substance, but at the expense of a fixed location - and thus must perpetually shuffle back and forth inside an office building somewhere in the country, minding all the isolated employees at work. Welcome to the new ontological world of "substance," à la luxembourgeoise.

\section{OFFSHORE ONTOLOGY \#2 - PLACELESSNESS}

A river of cash exists in a largely unregulated place known as the secrecy world. It's an alternate reality available only to those who can afford the trip (Bernstein 2017: 3).

A second common ontological intervention on offer in the Luxembourg financial center concerns presence - that is, where all the activity administered in its jurisdiction actually takes place. The offshore finance practiced in Luxembourg and its peer jurisdictions defies the ontology of citizenship that nurtured the rise of Western nation-states in the wake of the seventeenth-century Treaty of Westphalia. The consolidation of a country's legal system, and the corresponding development of its national tax base, was possible insofar as its citizens could not move between jurisdictions. So long as these people had to remain within the borders of the country, there was no distinction to be made between those who were physically located there and those who were legally citizens.

Offshore finance, however, scrambles this ontology entirely. Taking advantage of their Westphalian-era sovereignty to write laws, officials in Luxembourg and other offshore jurisdictions frequently draft legislation to help non-resident persons and corporations avoid the taxes and regulation imposed on them from "elsewhere" - that is, in those places where they undertake the substance of their economic activity (Ötsch 2016: 322). In doing so, the global system of offshore finance cannot be said to only occupy a Euclidean territorial space, such as that of the Grand Duchy of Luxembourg, but also an alternative one - simultaneously located every-where, no-where, and some-where in between these distinct realms.

What does this strange ontology of offshore space entail? By soliciting the pricey services of Luxembourg's "ontologists," wealthy individuals and companies can make it seem as if they reside in a place other than where they are actually located, or - for purposes of taxation - they can even disappear altogether. For a fee, clients and their operations can secure "virtual residence in virtual spaces" (Palan 2006: 4). In that they move constantly and with ease, the capital of these individuals and businesses is also liberated from the legal or moral entanglements that may arise in its locales of origin (Nuttall and Mbembe 2015: S32). In this light, it goes without saying that 
tiny Luxembourg is not really the world's second largest domicile of assets housed in investment funds, at almost $\$ 5$ trillion; as everyone knows, all this money comes from, and is housed, elsewhere.

"Elsewhere" is a place well known to generations of Luxembourg's ontologists. In the early 1960s, British regulators looked the other way when banks in the City of London ${ }^{5}$ began treating certain types of transactions - those between non-resident parties and denominated in U.S. dollars - as if they did not occur on UK territory. Curiously, the physical place where many of these transactions were logged as "booked" was a locality approximately 600 kilometers to the southwest of London: the Luxembourg Stock Exchange. Even though these transactions, which centered primarily on bond markets, were formulated and carried out in London, British regulators nevertheless deemed them to be taking place elsewhere. Under this new ontology, deals taking place in the emerging "offshore" landscape - dubbed the Euromarket ${ }^{6}$ - ended up under little, if any, regulation at all.

In a 2014 paper, Palan and Nesvetailova suggest the fledging Euromarket nexus - spanning London, Luxembourg, and places in between - was merely the first sign of things to come. As the pair argues, the breakneck post-1960s growth of offshore financial centers such as Luxembourg's, and globalized finance capitalism more generally, has been due in large part to the factor of "elsewhere." This curious ontological destination, they write, denotes "the principle of not being recognised, registered, accounted for, taxed, regulated, detected or understood well" (2014: 28). The specter of elsewhere, as a result, marks an ontological rupture in the Westphalian-era bond between the taxpayer and the jurisdiction levying the tax - resulting in transactions that physically take place in one country but are legally booked in another. For tax evaders, the advantages of this system are multiple, and are often enormously lucrative; at the first indication of an audit or legal inquiry, they can simply decamp to another jurisdiction. Their affairs, accordingly, cease to exist legally wherever the inquiry has arisen and now are "elsewhere."

In Luxembourg, the astonishing profitability of the Euromarket emboldened financial-center officials to further exploit the fertile ontological terrains of elsewhere. The guiding premise was to lure into Luxembourgish territory foreign taxpayers and their taxable transactions from wherever the real events actually occur. From the 1960s onward, accountants and lawyers (avocats d'affaires) began to construct an entire industry around this principle; they created dummy boards of directors for corporations whose shares were held anonymously by holding companies. The identities of the real owners, in turn, were kept secret via numbered bank accounts (comptes numérotés) covered by secrecy laws. Financial-center officials had thus succeeded in creating companies that were ontologically Luxembourgish and, as a result, were

\footnotetext{
${ }^{5}$ Akin to the Grand Duchy of Luxembourg, the square-mile City of London is another unique ontological space, having been governed since the ninth century by the independent City of London Corporation. The corporate nature of its governance enables the City to set its own policies and, as a result, confer special tax, legal, and financial privileges that do not exist elsewhere in the United Kingdom (see Peebles 2013).

${ }^{6}$ This should not be confused with the Euro currency $(€)$, which debuted in the early 2000 s and is currently used by 19 (of 28) EU member states, including Luxembourg.
} 
protected by national laws, but with assets originating and often physically located in other jurisdictions (cf. Palan 2006: 103-104).

As seen in this example, the geography of elsewhere affords its privileged denizens entry into an ontologically puzzling, but highly lucrative, no-person's-land as concerns taxes and regulation. Yet "elsewhere" is ultimately a misleading distinction, for - as we often see-exactly where this place is remains unspecified, and is frequently nonexistent. The "elsewhere" that has led to the explosive growth of offshore financial centers in Luxembourg and other tax havens frequently results in financial transactions being regulated nowhere (Palan et al. 2009: 81). The generalized geography of offshore finance, once scrutinized, dissolves quickly into no-place, or even an ontologically separate "space-time" (cf. Maurer 1995: 136). Murphy writes,

to locate [offshore] transactions geographically is not only impossible in many cases, it is also futile: they are not intended to be and cannot be located in that way. They float over and around the locations which are used to facilitate their existence as if in an unregulated ether (2009: 21; emphasis added).

To pose an ontological question: where could this offshore "ether" possibly be? Can it be both everywhere yet have no point of contact with the "real" world of, say, fields, forests, and rivers? It is significant that we see the celestial discourse of "ether" just at the moment when space is virtualized (O’Dwyer 2017). Financial centers such as Luxembourg's are "offshore" not because of the location they occupy, but rather due to their position within the virtual space of global computer networks. Invoking Harvey (1989), Maurer writes, "the tangled hierarchies of tax haven arrangements also move a step beyond time-space compression," thus confounding most attempts to locate the transactions taken in their name (1995: 136; emphasis added). Perhaps, then, we could say that presence - even "elsewhere" - is now ontologically unnecessary in jurisdictions such as Luxembourg, where Euclidean and Westphalian conceptions of the world simply dissolve into the alternate space-time of "offshore."

\section{OFFSHORE ONTOLOGY \#3 - SIMULATION}

"Luxembourg is cleaning up its act. It wants real companies, not just mailbox entities [sociétés boîte aux lettres]. It wants to undertake research and development for big companies that are tax substantial in Luxembourg. We want real business, not just fake, shadow business." (Local Corporate Attorney, Interview, January 2016)

A third ontological curiosity on offer in Luxembourg is simulation - that is, some-thing that exists, though in an imitative, altered, and often artificial form (Baudrillard 1981). As seen so far in the examples of substance-less Luxembourgish companies, whose activity takes place between elsewhere and nowhere, offshore jurisdictions such as Luxembourg offer a simulated form of nation-state and corporate governance in order to help their wealthy clients avoid regulation, taxes, and accountability in other countries. In this light, tax havens, as Palan asserts, convert "their sovereign rights" and ability to make contracts into "a source of revenue by turning themselves into attractive points on nomadic capitalism's eternal journal” (2006: 176).

What exactly is simulated, and thus ontologically unstable, in the Luxembourg financial center? The only physical trace of many of the country's banks and companies has long been a simple 
mailbox or a name plate in the lobby of an office building. In other words, branches of these banks or companies "exist" even as they undertake little activity. Nevertheless, what these premises do denote is some kind of presence in a jurisdiction that otherwise has minimal domiciliation requirements. They are commonly referred to as "empty shell" (coquille vide) or "brass plaque" operations (entreprise plaque en laiton) and, as is obvious, generally have littleto-no bearing on the actual activity of the bank or firm in question.

Thomas notes that while these simulated companies are technically illegal in Luxembourg, they are widespread and legal enforcement against them is rare. The current boom in "business centers" reveals that Luxembourg-based administrative services are as in demand as ever, even as they often amount to only a mailbox and a telephone line. He adds,

During police raids, it frequently was the case that the [business services] offices were unoccupied, the binders empty, and the computers disconnected. For an office of some meters squared, the rent hovers above 1,000 euros. To convert a floor into a business center for dozens of companies is otherwise more lucrative than renting an apartment there (2016b).

As is obvious, such arrangements imply a simulation of white-collar work that, alongside the multitude of substance-less companies and other entities, is indicative of the alternative ontologies for sale in the Luxembourg financial center.

Even the activity that does take place within the country's "business centers" (and similar establishments) nonetheless points to a simulated form of corporate governance. More often than not, this work is completed not by actual boards of directors, but rather by "nominees" or "dummy directors" - who can serve a similar function for scores, if not hundreds, of other companies (Palan et al. 2009: 86). ${ }^{7}$ Such employment may seem ontologically pointless, but it does fulfill several vital functions to the people who hire the "dummy directors" in the first place: anonymity, unaccountability, and secrecy. Given that Luxembourgish law requires that a company have a board of directors, nominees can fill this role. This simulated corporate governance, therefore, ensures confidentiality of a company's owners and shareholders against all sorts of prying eyes: foreign tax authorities, creditors, litigants, aggrieved family members, among other interested parties.

The curtain hiding this ontology of simulated governance was yanked away in the wake of the 2016 leak of the Panama Papers, in which four Luxembourg-based financial institutions were among the top 10 most frequently appearing clients of the disgraced Panamanian law firm Mossack Fonseca (Cravina de Sousa 2016). In sifting through these millions of documents, one can get a sense of what simulated corporate governance actually entails. Even in opaque Luxembourg, anyone can find out the identity of a company's board of directors. ${ }^{8}$ As mentioned

\footnotetext{
${ }^{7}$ These positions, which Graeber (2018) might call "bullshit jobs," nonetheless result in a lot of work, fees, and ultimately income for local professionals - and subsequently serve as a significant source of income-tax revenue for the Luxembourgish state coffers (Weeks 2018: 70-76).

${ }^{8}$ In January 2019, the Luxembourgish government mandated that all Grand Duchy-domiciled companies register publicly their "ultimate beneficial owners" - though as of September 2019, only 47 percent of affected entities have been deemed compliant; some 68,000 companies had not yet registered their beneficiaries with the Luxembourgish authorities (Reda-Jakima 2019).
} 
previously, the simplest way to avoid this is to resort to nominees, a service that Mossack Fonseca would duly provide in exchange for a fee. However, a lone layer of simulated governance rarely suffices. Officials in many offshore jurisdictions, such as the Seychelles, can still access the list of a company's shareholders and send this to, say, the French tax authorities (Baruch 2016). A "safer" alternative, therefore, is for the owners to not even appear among the shareholders. In again steps Mossack Fonseca. For a slightly larger annual fee than that for nominees, the firm will furnish a set of "dummy" shareholders. In the end, only Mossack Fonseca's employees - who are often mandated to remain silent about such arrangements due to national secrecy laws - will know the identity of the company's actual owner.

The last simulated activity taking place in the Luxembourg financial center is, ironically, financial activity itself. The record-beating amounts of assets flowing into the country - such as the nearly $\$ 5$ trillion housed in Luxembourg-domiciled investment funds - are ultimately misleading. Such money does not actually arrive in the country, but rather is simply registered there for tax and administrative purposes. These simulated "flows" nevertheless point to the alternative space-time of financial globalization, given that a good part of registered international transactions is considered "fictive" because it cannot be situated within Euclidean space-time (cf. Chavegneux 2015: 185). Harrington writes,

There is widespread agreement that the financial activity that takes place offshore is, at best, "fictional." That is, assets are never really deposited there, but instead are treated "as if" they passed through offshore institutions, though in reality these banks and firms are nothing more than "closets with computers" (2016: 132).

The "computers" to which Harrington refers are repositories of the contractual relationships taking place "on paper" in Luxembourg - and, as a result, serve only as administrative, or "booking," devices. Paradoxically, therefore, it is rare that the actual substance of a financial transaction will ever take place an offshore financial center such as that of Luxembourg.

\section{OFFSHORE ONTOLOGY \#4 - PERSONHOOD}

The state is the legal birth parent of all corporations and retains parental authority... How could such an awesome feat - the creation of an artificial person-be accomplished by the mere filing of a simple form, the "articles of incorporation"? (Bashkow 2014: 297)

Our next ontological exercise found in the Luxembourg financial center involves the "magic" by which the state is able to confer to companies the agencies, powers, and rights typically held by persons (Taussig 1997). As Welker argues, organizations such as corporations "merit the ontological status of actors because they possess the requisite traits: intentionality, responsibility, sovereignty, goals, values, self-reflexivity, and self-identity" (2014: 3). Indeed, to attain a proper ontological understanding of corporate personhood as it exists in Luxembourg necessitates comprehending more than just the law's role in the in-corporation of these companies. It also must account for how the thousands of "corporate persons" who call Luxembourg home are implicated in the daily life of the country - socially, economically, and politically.

Corporate personhood has long been studied by historians and anthropologists. In Western Europe of the late Medieval Period, as the late Ernst Kantorowicz informed us, the incorporated entity was initially conceived of not as a political or legal construction, but in theological terms: 
starting in the thirteenth century, the world "began to be populated by immaterial angelic bodies, large and small: they were invisible, ageless, sempiternal, immortal, and sometimes even ubiquitous; and they were endowed with a corpus intelectuale or mysticum which could stand any comparison with the 'spiritual bodies' of the celestial beings" (Kantorowicz 1997: 283; cited in Welker, 2014: 3).

Come the nineteenth century, however, this spiritual ontology had given way to "corporate personality," akin to what exists in the present-day Luxembourg financial center. In Santa Clara County v. Southern Pacific Railroad Company, from 1886, the U.S. Supreme Court declared that incorporated companies were duly "persons" and thus protected by the Fourteenth Amendment. In aftermath of this landmark decision, the rights afforded to individuals under the U.S. Constitution and its amendments - such as due process, equal protection under the law, the right to counsel and trial by jury, and, in the case of the recent and notorious Citizens United and Hobby Lobby cases, freedom of speech and religion - have been subsequently extended to the country's companies as well (Winkler 2018).

The world's many forms of "corporate personhood" and their associated ontologies - as found in the United States, Luxembourg, and other countries - have also caught the attention of generations of anthropologists and other social scientists. Contrary to the epistemological or juridical purview of historians, as cited above, anthropologists have been more attuned to the ways in which actual persons give "life" and meaning to companies as actors with constituent parts, relations, interests, and boundaries. Latour (2005) demonstrates how corporations and other social entities are relative, situational, emergent, and dispersed - the product of temporary interactions between persons and other beings, objects, and technologies in particular times and places. Welker cites the relational models from classic studies in South Asian and Melanesian social anthropology to show how contemporary corporations, akin to persons, are "partible (subject to external claims and extractions), composite (made up of heterogeneous parts), and permeable (assimilating ideas and substances from the outside)" (2014: 4-5). Foster (2010) and Bashkow (2014) show how individuals become unified in corporate entities via power of the state and the agency of its law. Such "magic of the state" (Taussig 1997) is potent indeed, conferring on companies in many jurisdictions the same freedom of contract and ability to own and sell property afforded to "natural persons." Yet, as Bashkow reminds us, affording personlike freedoms to a corporation also necessitates summoning the "causative agency" of actual people to hold its meetings, maintain records, and keep track of expenses (2014: 297).

What are the reasons why person-like companies and the incorporated entities of persons are ontologically similar in the contemporary Luxembourg financial center? In addressing this question, can we draw any parallels with Kohn's Andean account of "animals and spirits [having] a kind of interiority or selfhood that is comparable with that of human persons" (2015: 317)? To continue the proposition: in Luxembourg, can a corporation come to resemble a person in the same way that "a shaman can become a jaguar by wearing as clothing elements of a feline body, such as canine teeth and spotted hides" (Kohn 2015: 317)? Similar to Kohn (2013, 2015), I would answer in the affirmative: notwithstanding their obviously different physical compositions, persons and corporations in the Grand Duchy do express widespread ontological continuity. 
Indeed, personhood affords a number of material advantages to the thousands of companies currently incorporated in Luxembourg. First, the country's companies have long held privacy rights similar to those given to persons, thus enabling owners to conceal their identity via incorporation and subsequently carry out business that they would likely not be able to conduct under their own name. Frequently, this means that no actual person can be identified as the beneficiary owner of the assets - and, as a result, no one can be held accountable for any taxes or judicial decisions levied on the underlying interests (cf. Harrington 2016: 192).

The second advantage conferred to Luxembourg-incorporated companies stems from their divisible nature - that is, entities that are ontologically separate from the people who own them. Due to this "corporate personhood," owners are thus not personally responsible for any debts, bodily injuries, broken contracts, or liabilities stemming from the company's activities. While such arrangements are the foundation of corporate law in many countries, the Luxembourg financial center nevertheless takes the separation of the company from its owner(s) a step further. Via a number of Luxembourg-based corporate structures, owners are able to reside in one jurisdiction while having their assets housed in another. Thus, what living individuals cannot do, Luxembourg-incorporated companies can - that is, spread themselves physically over different jurisdictions at the same time.

The final ontological advantage bestowed to the owners of Luxembourg-based companies is that corporate personhood in the country entails no corpus, or body. While many may lament this only a natural person can, after all, laugh and dance - the corporate entity employing personhood as mere metaphor, or as technical legal fiction, nonetheless results in an incredibly effective and forceful exercise of commercial and political power. By shedding the material and legal constraints of the human body, wealthy individuals and multinational companies can move around the world with few restrictions, summoning mobile infrastructures while reaping spectacular profits (Foster 2010: 99). It is precisely within this nexus - "the 'idea' of the corporation as an actor endowed with particular goals and rationalities [and its] corresponding 'system' of material relations and practices" (Welker 2014: 4) - that I situate this present analysis.

\section{OFFSHORE ONTOLOGY \#5 - INVISIBILITY}

The irrational desire to corner the market in some commodity, the counterintuitive search for magical formulas to predict price changes... all these are the product of this complete conversion of commodities to signs... which are themselves capable of yielding profit if manipulated properly (Appadurai 1986: 51).

A final ontological intervention for sale in the Luxembourg financial center is the ability to hide that which should otherwise be visible. This ability should not come as a surprise; Palan and Nesvetailova note that much of global finance is deeply dependent on the invisibility for sale in Luxembourg and other secrecy jurisdictions. The overall financial system, they write, is "heavily reliant on obscure and opaque practices and spaces, such as offshore financial havens [and] shadow banking entities" (2014: 27; emphasis added). Whether implicated in the opaque structures or "shadow" entities referenced above, or - as we shall see - magical or even 
supernatural forces, this generalized Euclidean invisibility is undoubtedly a primary reason why wealthy individuals and businesses opt to confer a Luxembourg domicile to their assets.

The term "shadow banking" was on the lips of many Western commentators as the global financial crisis of 2008-09 unfolded. It was, they surmised, shadow banking activities that could have possibly brought down the entire financial system, even its regulated and "visible" parts. This begs the question: what exactly takes place "in the shadows" of Luxembourg and other jurisdictions? Implied here is that the transactions and intermediation undertaken by otherwiseregulated banks are carried out in such a way that they remain invisible to all regulatory authorities. Palan and Nesvetailova speak to the ubiquitous nature of this activity:

In the USA on the eve of the crisis, the scale of the shadow banking industry was estimated to be one and a half times larger than the official, "visible" banking sector. In Europe, recent estimates suggest that [shadow banking] practices have actually grown in scope after the crisis of 2008-09 (2014: 27).

What keeps certain pursuits of regulated banks "in the shadows" is undoubtedly the services found in offshore financial centers such as Luxembourg's. After all, the massive growth of shadow banking is largely predicated on the invisibility on offer in secrecy jurisdictions worldwide - that is, the ontological ability afforded to rich clients to not be documented, accounted for, or even identified.

For many clients, however, "the shadows" - no matter how dark, impenetrable, or obfuscating provide insufficient cover from the prying eyes of tax authorities, creditors, or heirs. Some prefer the ontology of magic instead. Via the deployment of shell companies, secret bank accounts, and dummy foundations, the ontologists of the Luxembourg financial center can initiate an end-less game of "now you see it, now you don't... leaving clients' [assets] to grow untouched" (Harrington 2016: 9; emphasis added). How can one produce wealth in Luxembourg as if by magic? Via their administrative dexterity and the filing of paperwork with the proper authorities, the ontologists of the country's financial center labor to make the tax liabilities of individuals and companies disappear. These clients' newly minted Luxembourg companies can undertake the simulated managerial practice of "charging" themselves for paying bills and using intellectual property in their countries of operation, thus reducing (or eliminating) the net taxable income of otherwise profitable entities.

As discussed previously, the very "magic" endowing these Luxembourg companies with their person-like capacities is, of course, "accomplished by the power of the state through the agency of the law" (Bashkow 2014: 296; cf. Foster 2010). The symbolism and imagery of offshore money as resulting from state magic suggests a sort of fetishism in which extra-ordinary powers can bestow infinite reproducibility to capital. As Marx reminds us, under capitalism, money breeds yet more money, "much as it is an attribute of pear trees to bear pears" (cited in Parry and Bloch 1989: 6). Indeed, one need look no further than all the offshore money as ontological proof of the magical and fetishistic powers of the Luxembourgish state.

Within the Luxembourg financial center, the ontological endpoint of the continuum beginning with "shadows" and proceeding to "magic" is none other than the supernatural. This is as much the case for financial-center practitioners as it is for their individual and corporate clients. In Luxembourg, we see how the administration of capital attains a quasi-sacramental character. 
Ziegler's characterization of Geneva's bankers is equally valid for their counterparts in the Grand Duchy: "holding money, accepting it, counting it, hoarding it, speculating and receiving, are all activities which... have been invested with an almost metaphysical majesty" (1979: 48). Yet, if we are to take seriously the work of financial ontologists in Luxembourg, Switzerland, and other countries, it would require us to view their activity not as metaphysical in nature, but rather that of an entirely different physics all together.

Irrespective of in whose possession it is, offshore money in the Luxembourg financial center nonetheless assumes a supernatural ability to align the interests of its administrators with those of its clients. Those who talk too much about these activities commit the "sin" of breaking their vows to banking secrecy, for such sacrilege is punishable under multiple Luxembourgish statutes. As I have detailed elsewhere (Weeks 2018: 266-280), the country's banking-secrecy laws, first passed in 1981, were premised on a ruling from the country's nineteenth-century criminal code, which implies that priests cannot divulge any information that they have heard from a confessing parishioner. As a result, in Luxembourg, bankers are charged with the supernatural responsibilities usually afforded to priests; both learn about the more delicate aspects of someone's life but are legally bound to keep this information secret. To do otherwise is not just to violate the bonds of interpersonal trust from one's professional code, but also is to offend the country's theological order itself.

\section{CONCLUSION}

The desire and fantasy of the offshore for some becomes the lived inequality and exploitation of others (Appel 2019: 61).

Does the ontological nature of the activities within the Luxembourg financial center serve to "hide the relationships of power and dominance that structure [them]" (Maurer 1995: 138)? In all likelihood, yes. But there is more. As I posit in this article, officials in Luxembourg have long endowed the offshore money in their care with a unique ontology - at once immaterial, placeless, simulated, incorporated, and invisible - that they link to the practices of unequal distribution on offer in the financial center. Even as proponents cling to ontology in an effort to naturalize and de-politicize their actions, its ubiquity nonetheless points to the widespread thinning of liability, accountability, and responsibility among the corporate actors who dominate today's contested and fragmentary global economy. As is obvious then, the offshore ontologies for sale in Luxembourg are not as immaterial, placeless, simulated, incorporated, and invisible as their buyers and sellers no doubt desire. While they appear to constitute a "capitalist utopia of placeless economic interaction" (Appel 2019: 77), they also represent global elites' exercise of raw corporate power in the endless search for profits and "safety" from redistributive pressures.

It is for contexts such as the Luxembourg financial center where I believe the concepts and approach of a politicized, ontological anthropology are especially appropriate. Complex socioeconomic systems such as this one demonstrate that ours is no longer an "open society," but is rather one made up by overlapping social and physical configurations characterized by opacity, exclusion, and structural violence (cf. Feldman 2011). However, just because our own actions are circumscribed by the world of capitalist markets and Westphalian states does not mean we cannot - at certain times, in certain places, and with certain tools - intercede or impinge upon the 
alternative ontologies around us, such as those found in the Luxembourg financial center. The 2016 leak of the Panama Papers was one such rupture, wherein offshore ontologies are revealed to be a basis for all kinds of instability within the legal, fiscal, and monetary orders of the Westphalian system.

In this article, I have demonstrated that intervening within Luxembourg's offshore space-time is a complicated but not impossible task. With this example in mind, I hope to nudge other anthropologists in similar directions in the hope that we will be better able to make sense of the many emerging ontologies out there. The world's physical geography has been nearly all mapped, save for a few hard-to-reach places. We know much less, in contrast, about the present terrain of inchoate social ontologies, such as those constituting the Luxembourg financial center. Here is where ontological anthropology holds its greatest political and analytical promise, for we are as disoriented amid these new ontologies as Malinowski was when he first set foot on the Trobriand Islands in 1915.

\section{REFERENCES}

Appadurai, Arjun. 1986. Introduction: Commodities and the politics of value. In The social life of things: Commodities in a cultural perspective, ed. Arjun Appadurai, 64-93. Cambridge: Cambridge University Press.

Appel, Hannah. 2019. The licit life of capitalism: U.S. oil in Equatorial Guinea. Durham, NC: Duke University.

Baruch, Jérémie. 2016. Comment dissimuler son argent sans peine. Le Monde, 6 April.

Bashkow, Ira. 2014. What kind of person is the corporation? PoLAR: Political and Legal Anthropology Review 37(2): 296-307.

Baudrillard, Jean. 1981. Simulacres et simulation. Paris: Editions Galilée.

Bennett, Jane. 2010. Vibrant matter: A political ecology of things. Durham, NC: Duke University Press.

Bernstein, Jake. 2017. Secrecy world: Inside the Panama Papers investigation of illicit money networks and the global elite. New York: Henry Holt and Company.

Bessire, Lucas, and David Bond. 2014. Ontological anthropology and the deferral of critique. American Ethnologist 41(3): 440-456.

Blaser, Mario. 2013. Ontological conflicts and the stories of peoples in spite of Europe: Toward a conversation on political ontology. Current Anthropology 54(5): 547-568.

Boellstorff, Tom. 2016. For whom the ontology turns: Theorizing the digital real. Current Anthropology 57(4): 387-407. 
Braidotti, Rosi. 2013. The posthuman. Cambridge: Polity.

Candea, Matei. 2014. The ontology of the political turn. Theorizing the Contemporary: Fieldsights, 13 January.

Chavagneux, Christian. 2015. Luxembourg : un paradis fiscal sur la sellette. In Un monde d'inégalités - L'état du monde 2016, eds. Bertrand Badie and Dominique Vidal, 182187.Paris: Editions La Découverte.

Cravina de Sousa, Paula. 2016. Panama Papers: Luxemburgo ajudou a criar empresas offshore. Contacto, 6 April.

Descola, Philippe. 2005. Par-delà nature et culture. Paris: Gallimard.

Dörry, Sabine. 2016. The role of elites in the co-evolution of international financial markets and financial centers: The case of Luxembourg. Competition \& Change 20(1): 21-36.

Dvas, Nick. 2015. This country could be the next fin-tech hot spot. www.cnbc.com/2015/12/28/this-country-could-be-the-next-fin-tech-hot-spotcommentary.html. Accessed 4 October 2019.

Feldman, Gregory. 2011. The migration apparatus: Security, labor, and policymaking in the European Union. Stanford, CA: Stanford University Press.

Fischer, Michael M. J. 2013. Double-click: The tables and language games of Latour and Descola, or, From humanity as technological detour to the peopling of technologies. Paper presented at the 112th Annual Meeting of the American Anthropological Association, Chicago, 22 November.

Foster, Robert J. 2010. Corporate oxymorons and the anthropology of corporations. Dialectical Anthropology 34(1): 95-102.

Graeber, David. 2018. Bullshit jobs: A theory. New York: Simon \& Schuster.

Hage, Ghassan. 2012. Critical anthropological thought and the radical political imaginary today. Critique of Anthropology 32(3): 285-308.

Harrington, Brooke. 2016. Capital without borders: Wealth managers and the one percent. Cambridge, MA: Harvard University Press.

Harvey, David. 1989. The condition of postmodernity: An enquiry into the origins of cultural Change. Malden, MA: Blackwell.

Henare, Amira, Martin Holbraad, and Sari Wastell (eds.). 2007. Thinking through things: Theorising artefacts in ethnographic perspective. Oxford: Routledge. 
Holbraad, Martin, Morton Axel Pedersen, and Eduardo Viveiros de Castro. 2014. The politics of ontology: Anthropological positions. Theorizing the Contemporary: Fieldsights, 13 January.

Jensen, Caspar Bruun. 2017. New ontologies? Reflections on some recent "turns" in STS, anthropology and philosophy. Social Anthropology/Anthropologie sociale 25(4): 525545.

Kantorowicz, Ernst H. 1997. The king's two bodies: A study in medieval political theology. Princeton, NJ: Princeton University Press.

Kapferer, Bruce. 2011. Legends of people, myths of state: Violence, intolerance, and political culture in Sri Lanka and Australia. London: Berghahn Books.

Kohn, Eduardo. 2013. How forests think: Toward an anthropology beyond the human. Chicago: University of Chicago Press.

Kohn, Eduardo. 2015. Anthropology of ontologies. Annual Review of Anthropology 44: 311327.

Latour, Bruno. 1984. Pasteur : guerre et paix des microbes. Paris: Editions La Découverte.

Latour, Bruno. 1991. Nous n'avons jamais été modernes. Paris: Editions La Découverte.

Latour, Bruno. 2005. Reassembling the social: An introduction to actor-network-theory. Oxford: Oxford University Press.

Law, John, and John Hassard. 1999. Actor network theory and after. Oxford: Blackwell.

Londoño Sulkin, Carlos D. 2005. Inhuman beings: Morality and perspectivism among Muinane people (Columbian Amazon). Ethnos 70(1): 1-24.

Maurer, Bill. 1995. Complex subjects: Offshore finance, complexity theory, and the dispersion of the modern. Socialist Review 25(3/4): 113-45.

Murphy, Richard. 2009. Defining the secrecy world. Rethinking the language of "offshore." London: Tax Justice Network.

Neate, Rupert. 2016. Trump and Clinton share tax "loophole" address with 285,000 firms. The Guardian, 25 April.

Nuttall, Sarah, and Achille Mbembe. 2015. Secrecy's softwares. Current Anthropology 56(S12): S317-S324.

O’Dwyer, Rachel. 2017. Ether. In Paid: Tales of dongles, checks, and other money stuff, eds. Bill Maurer and Lana Swartz, 237-248. Cambridge, MA: MIT Press. 
Ötsch, Silke. 2016. The offshore coalition, its tactics and strategies. American Behavioral Scientist 60(3): 321-339.

Palan, Ronen. 2006. The offshore world: Sovereign markets, virtual places, and nomad millionaires. Ithaca, NY: Cornell University Press.

Palan, Ronen, and Anastasia Nesvetailova. 2013. Elsewhere, ideally nowhere: Shadow banking and offshore finance. Politik 16(4): 26-34.

Palan, Ronen, Richard Murphy, and Christian Chavagneux. 2009. Tax havens: How globalization really works. Ithaca, NY: Cornell University Press.

Parry, Jonathan, and Maurice Bloch. 1989. Introduction: Money and morality of exchange. In Money and morality of exchange, eds. Jonathan Parry and Maurice Bloch, 1-32. Cambridge: Cambridge University Press.

Pedersen, Morten Axel. 2011. Not quite shamans: Spirit worlds and political lives in northern Mongolia. Ithaca, NY: Cornell University Press.

Peebles, Gustav. 2013. Washing away the sins of debt: The nineteenth-century eradication of the debtors' prison. Comparative Studies in Society and History 55(3): 701-724.

Reda-Jakima, Zuzanna. 2019. Deadline delayed as firms leave list to shed light on owners vacant. Luxembourg Times, 29 August.

Roberts, Susan. 1994. Fictitious capital, fictitious spaces: The geography of offshore financial flows. In Money, power and space, eds. Stuart Corbridge, Nigel Thrift, and Ron Martin, 91-115. Oxford: Blackwell.

Sahlins, Marshall. 2013. Foreword. In Beyond nature and culture, ed. Philippe Descola, xi-xiv. Chicago: University of Chicago Press.

Smith, Geoffrey. 2014. Leaked files from Luxembourg show "industrial-scale tax avoidance." Fortune, 6 November.

Taussig, Michael. 1997. The magic of the state. New York: Routledge.

Thomas, Bernard. 2016a. Le gardien du temple : Entretien avec Guy Heintz. D’Lëtzebuerger Land, 2 December.

Thomas, Bernard. 2016b. Quest for substance. D'Lëtzebuerger Land, 29 January.

Tsing, Anna Lowenhaupt. 2015. The mushroom at the end of the world: On the possibility of life in capitalist ruins. Princeton, NJ: Princeton University Press. 
Viveiros de Castro, Eduardo. 2009. Métaphysiques cannibales. Paris: Presses universitaires de France.

Walker, Owen. 2017. Luxembourg expects more companies to leave over tax scrutiny. Financial Times, 5 February.

Weeks, Samuel. 2018. Secrecy and consensus: The governmentality of an offshore financial center in Europe. Ph.D. Dissertation, University of California-Los Angeles.

Welker, Marina. 2014. Enacting the corporation: An American mining firm in post-authoritarian Indonesia. Berkeley and Los Angeles: University of California Press.

Winkler, Adam. 2018. We the corporations: How American businesses won their civil rights. New York: W. W. Norton \& Company.

Ziegler, Jean. 1979. Switzerland: The awful truth. New York: Harper and Row. 